\title{
APPLICATION OF UNIVERSAL ONTOLOGY OF GEOGRAPHIC SPACE IN A SUBSET OF THE FIRST-ORDER PREDICATE CALCULUS
}

\author{
IZVEDBA UNIVERZALNE ONTOLOGIJE GEOGRAFSKEGA PROSTORA V \\ PODMNOŽICI PREDIKATNEGA RAČUNA PRVEGA REDA
}

\author{
Marjan Čeh, Domen Smole, Tomaž Podobnikar
}

UDK: 004:111:659.2:91

\begin{abstract}
Spatial data sources, like the geodetic reference system, administrative spatial units, addresses and topographic maps, serve as a base for geo-referencing to the most of dependant thematic spatial databases. The marketing strategy of the surveying profession towards the users of spatial data infrastructure should be in the design of an integrative semantic reference system to be used within the Semantic Web, or so-called Web 3.0. The main motivation for our research was the representation of possibilities to automate tool development for efficient and more sensible approaches to query information within web-published spatial data. In contemporary research there are several solutions offered as upgrades of basic GIS systems with the knowledge presented in the form of ontologies. Therefore, we are faced with the new generation of GIS technology, which has been named "inteligent GIS". In this article, we present method of modelling the semantic reference system as an application of the ontology of geographic space in the subset of first order predicate calculus. Such a semantic network of geographic space represents the foundation for semantic data analyses and data integration in distributed information systems. Our application is based on the methods of machine learning and use of the Prolog programming language.
\end{abstract}

\section{KEY WORDS}

ontology, Semantic Web, geographic space, logic, predicate calculus
Klasifikacija prispevka po COBISS-u: 1.01

\section{IZVLEČEK}

Prostorski podatkovni viri, kot so geodetski referenčni sistem, administrativne prostorske enote, naslovi in topografske teme, so $v$ vseh prostorskih podatkovnih zbirkah podlaga za zajem podatkov in položajno umeščanje tematskih podatkov v prostoru. Temeljne strategije geodetske stroke za približevanje potrebam uporabnikov geodetskih podatkov v smislu povezovanja zbirk podatkov so v oblikovanju povezovalnega semantičnega referenčnega sistema $v$ semantičnem spletu ali tako imenovanem spletu 3.0. V tem prispevku so prikazane možnosti za razvoj orodja za enostavnejše in bolj smiselno iskanje ter integracijo na spletu objavljenih prostorskih podatkov. Za rešitev težave je $v$ raziskavah mogoče zaslediti predloge o nadgradnji sedanjih GIS kot sistemov z znanjem, predstavljenim v obliki ontologij. Gre torej za novo generacijo tehnologije GIS, ki jo nekateri imenujejo tudi pametni GIS. Za zdaj takšen GIS obstaja predvsem na teoretični, ne pa tudi na praktični ravni. V tem delu je predstavljena metoda za modeliranje ontologije geografskega prostora v podmnožici predikatnega računa prvega reda. Izdelano semantično omrežje prostora omogoča analize obstoječih zbirk podatkov za namene integracije $v$ okolju porazdeljenih informacijskih sistemov. Naša izvedba temelji na metodah strojnega učenja in uporabi programskega jezika prolog.

\section{KLJUČNE BESEDE}

ontologija, semantični splet, geografski prostor, logika, predikatni račun 


\section{INTRODUCTION}

Spatial data like the geodetic reference system, spatial administrative units, addresses and topographic maps serve as the primary spatial reference for all other spatial data. The basic strategy of the surveyor's profession involves adapting the services and products to the customers by interrelating spatial data also through the semantic reference system using the Semantic Web 3.0 (Berners-Lee et al., 2001; Brickley et al., 2004; Berners-Lee, 2010).

The main goal of this research is the application of taxonomy Universal Ontology of Geographic Space (UOGS) developed by Čeh (2003) and its representation in the programming language which supports the concepts of logics and predicate calculus. Geographic space is considered as the composition of spatial objects of geographic dimension, larger than the human body and not fully perceivable within one cognitive act (Egenhofer and Mark, 1995).

The main features of UOGS are hierarchic taxonomy, independence of spatial objects, concepts represented by natural language words/symbols, universal dimension considering the whole domain of geographic space, simply expandable by combining basic concepts into complex ones. Theoretically, UOGS could be treated as an appropriate tool for querying of a spatial database since we know that the desired characteristic of query languages and user interfaces is to offer users search and integration of information without knowing the names and the structure of the database (Podobnikar, Čeh, 2012).

The ontology UOGS serves as a link between the user and the applications of spatial database concepts. The user forms a query with available concepts of UOGS and simultaneously defines the required level of semantic matching (Čeh et al., 2004; 2006; Smole et al., 2011). Such a query concept is for example »objects of education activity«.

In this research we analysed Slovenian database catalogues and interpretation keys as follows:

- Catalogue of cadastral classification of land (UL SRS, No. 16/74, UL SRS, No. 42/86)

- Catalogue of land use of Slovenian agricultural land - Land Parcel Identification System (GERK)

- Catalogue of CORINE land cover

- Catalogue of large scale topographic maps (TNN VM 500)

- Catalogue of the topographic database (TOPO 5)

- Catalogue of spatial shapes (at SMARS)

In the framework of this research we proposed the »manual« editing of documents (mostly in HTML format) to define the frequency of mentioning the concepts in every treated document. For the application of such semi-automated process of rules detection in text, the most useful approach is text mining. We represent the concepts of UOGS with the first-order predicate calculus in the Prolog language. Basically, the users can query interactively through the taxonomy of UOGS. 


\section{METHODOLOGY}

The proposed methodology comprises computer engineering management of ontology with machine learning and the use of first-order predicate calculus (logic).

\subsection{Computer engineering management of ontology}

The exchange of metadata and information between different geographic databases requires an appropriate method formally defining and enabling machine representation of knowledge about the geographic space. For the acquisition of semantic knowledge we have developed querying and integrative tools using the methods of computer learning for knowledge discovery.

It is required that the automated integration tool is »intelligent«, so that it discovers and solves the maximum of semantic disagreements, while in case of unsolved disagreements it offers the most information possible for decision support. The querying and integration tools must have certain knowledge, e.g. relational knowledge, such as a glossary of synonyms.

The comparison and integration of schemata was extended from the domain of computer engineering to geographic data management (Spaccapietra et al., 1992; Devogle et al., 1998). Geosciences have adopted the communication theory and the methods of relations comparison (Sester et al., 1998) as well as the ontologies from the field of artificial intelligence (Vet and Mars, 1998).

Knowledge discovery in the database as part of data mining methodology is reported by several researchers (Keim et al., 1994; Knorr et al., 1997; Leung, 2000; Miller, 2008). The mining of spatial data includes pattern and relation recognition between the entities in a database. Such an approach can manage the dynamic nature of spatial phenomena. Spatial data mining requires a conceptual framework for systematic search through vast, varied and dynamic spatial databases.

Most algorithms of spatial data mining take into account the adjacency relationship between neighbouring objects and their attributes. There is a tendency of integration of spatial data mining algorithms with spatial data base management systems (SDBMS) (Ester et al., 1997).

Several methodologies exist for the implementation of »reasonable« querying and integration of spatial data:

- Integration of semantic knowledge from various sources and construction of an integrated database (local conceptual scheme, integration experience, user requirements);

- Knowledge extraction from field experts with techniques applied in expert systems and methods of machine learning (Hayne and Ram, 1990);

- Criteria definition for semantic similarity with application of fuzzy sets theory and reasoning theory;

- multiagent method for automatic generation of knowledge models such as ontologies from arbitrary tabular structures found on the Web (Pivk, 2005);

- semantic thesauri application with descriptive logic and predicate calculus.

In our research we used the method mentioned last in the list above. 


\subsection{Machine learning and the use of first-order predicate calculus}

Learning means every change of the system, which offers the possibility of a more effective execution. The result of learning is knowledge usable by the system for solving new tasks. Knowledge can be (Kononenko, 2005):

- a group of memorized data,

- an algorithm for problem solving,

- a group of axioms for more efficient problem solving.

Machine learning can be defined as a description or modelling of data. In dealing with machine learning systems we distinguish between the learning algorithm which creates new knowledge from a group of data, and the execution algorithm, which uses the learned knowledge for solving new problems automatically. The input into the system is presented by preknowledge and a group of data, the output is generated as a description (model, hypothesis, theory) which describes the data and the preknowledge. The group of possible models is considered in the preknowledge. Among the available models the algorithm searches the one which is most appropriate for input data while it simultaneously considers the criterion of optimality. Preknowledge can include the initial hypothesis, which can be an approximate solution to the problem, and a group of heuristics which serve as a guide into the more promising parts of the preknowledge space. An appropriate presentation is necessary for preknowledge, learning cases and the space of hypotheses. The following knowledge presentations are distinguished (Kononenko, 2005):

- statement logic,

- first-order predicate calculus,

- discriminatory and regression functions,

- probability distributions.

The first-order predicate calculus, compared to statement logic, enables the description of the relations among objects and the use of universal and existential quantification variables. In the field of machine learning it is common to use only the subset of the first-order predicate calculus, namely the Horn clauses and negated literals, since the learning process in the unlimited predicate calculus would be too complicated. Such a subset corresponds well to the statements of the Prolog programming language. In the domain of the machine learning subset it is called Inductive Logic Programming (Džeroski and Lavrač, 2001).

The characteristics of the first-order predicate calculus allow for modelling of concepts from the UOGS taxonomy and their relations as it was demonstrated in this research. The programme is available for free and operates on the premises of Inductive Logic Programming. The proposed method, data, results and discoveries are applied in programming environment »Amzi! Prolog + Logic Server . 


\section{RESULTS}

Spatial database manual semantic enrichment with the concepts of UOGS is a rather time consuming task. The reason to switch to semi-automated indexation for spatial database is why the success of query engines mostly depends on the number of indexed documents.

Previous work consists of manual description of six Slovenian spatial databases with the concepts of UOGS, described fully in Čeh (2003). The whole UOGS taxonomy is a composition on five levels. The results comprise the application of presentation, semantic correspondence analyses of UOGS and analyses of semantically non-correspondent concepts.

\subsection{Presentation of UOGS taxonomy}

First we developed the tool called »HIT«, which allows a simple setting of concepts into the interrelations of the taxonomy. The user inputs, edits and deletes the elements of the taxonomy. The application enables copying the creation of any hierarchy of concepts with the relation »implies« with Prolog sentences into a text file. The relation named »implies«, which expresses C or parent relationship between a pair of concepts in a given taxonomy, is labelled with predicate »is-child-of « with the Prolog language (Bratko, 2001).

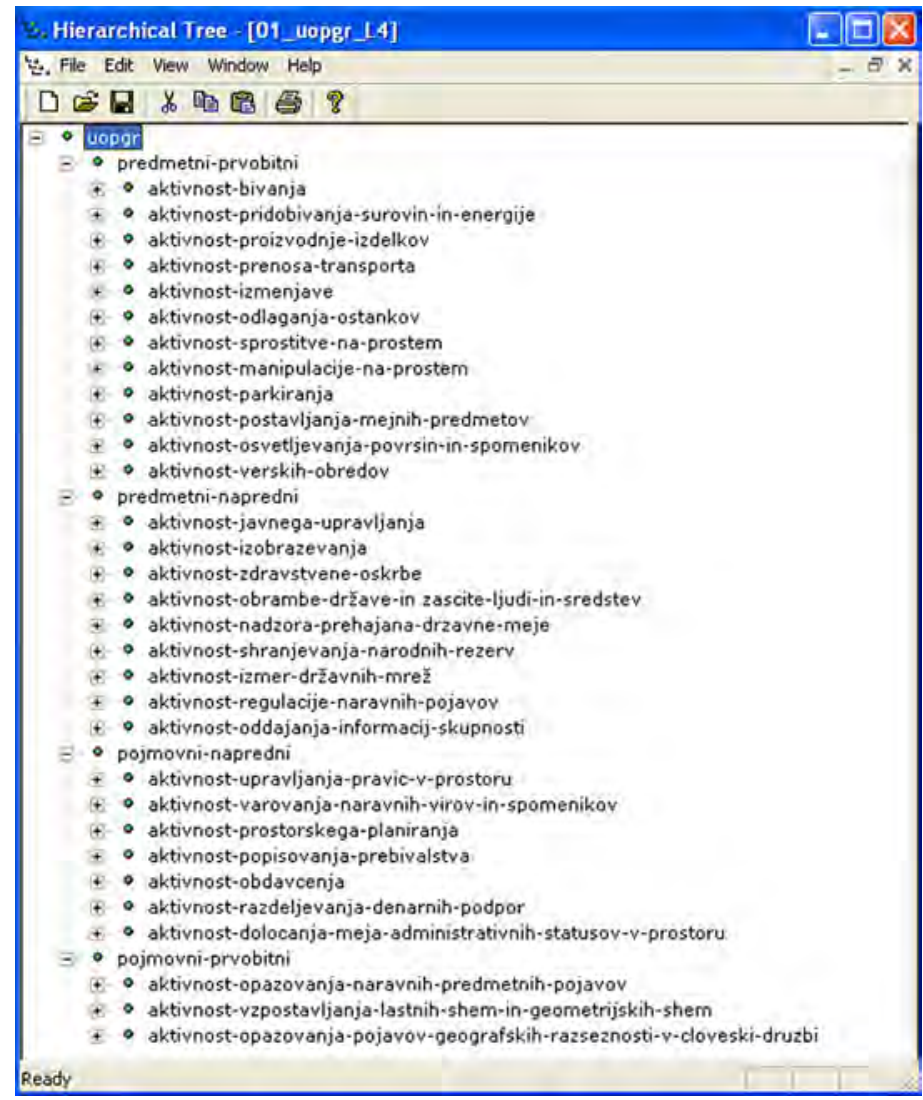

Figure 1: HIT tool and UOGS tree. 
The Prolog database exported from the HIT tool is a composition of facts, which describe the parent/subordinate relations between concepts with predicate $»$ implies/2«. The purpose of such a user interface is to support the user in his querying of concepts in a spatial database, which describes/implies the searched concepts and their more or less semantically similar concepts. The similarity, correspondence of two concepts in the first phase of the research is given as the distance within ontology. A short excerpt from the database is given:

implies(physical-basic,uogs).

implies(physical-advanced, uogs).

implies(abstract-advanced, uogs).

implies(abstract-advanced, uogs).

implies(activity-residence, physical-basic).

implies(activity-extraction-materials-and-energy, physical-basic).

implies(activity-production-products, physical-basic).

implies(activity-transportation, physical-basic).

implies(activity-exchange, physical-basic).

implies(activity-depositing-remains, physical-basic).

implies(activity-relaxation-outside, physical-basic).

implies(activity- handling -outside, physical-basic).

implies(activity-parking, physical-basic).

implies(activity-setting up-boundary-monuments, physical-basic).

In Prolog we wrote a program code offering user queries. Here we present part of the queries and the results where first predecessors and then successors are indicated:

?- predecessor(X,house).

$\mathrm{X}=$ daily - residence;

$\mathrm{X}=$ uogs ;

$\mathrm{X}=$ physical - basic ;

$\mathrm{X}=$ activity - residence ;

no

?- predecessor(house, Y).

no

?- predecessor(activity - residence, $Y$ ).

$\mathrm{Y}=$ daily - residence;

$\mathrm{Y}=$ non daily - and - seasonal - residence;

$\mathrm{Y}=$ house ;

$\mathrm{Y}=$ apartment block ; 
$\mathrm{Y}=$ skyscraper

$\mathrm{Y}=$ residence - unit;

$\mathrm{Y}=$ vacation - house;

$\mathrm{Y}=$ gardening - house;

$\mathrm{Y}=$ shepherd - house;

no

The content of searches is given in a metadata document, that is, in an object catalogue of spatial data, which is published in the central register of metadata descriptions (e.g. The Surveying and Mapping Authority of the Republic of Slovenia metadata homepage).

\subsection{Short description of processed catalogues and interpretation keys of spatial data}

In this chapter we give short explanations of processed catalogues and interpretation keys of spatial databases.

\section{Catalogue of cadastral classification of land}

Cadastral classification is intended to define land parcel suitability for agricultural and forestry production through cadastral use (cultures) and to determine the production capability level (class) of any land parcel within the cadastral region. We have used the version of cadastral classification described in Land Cadaster Act (1986), which defines 4 groups (cadastral cultures, land below construction, green areas, infertile land) and land use (37 categories), within the Standard (classification of land in cadastre, 1982).

Catalogue of land use of Slovenian agricultural land - Land Parcel Identification System (LPIS)

The registration of the present agricultural land use is a multipurpose task. The basic intention of collecting such data is decision support to increase the efficiency of agricultural production. The secondary aim of the registration is the control of data presented in farmers' documentation for various land interrelated financial subsidies. Agricultural land use concepts are defined to differentiate data recognised on digital orthophoto images. Beside agricultural land, forest land and urban land are also registered, but in a more rough way.

\section{Catalogue of CORINE land cover}

The basic aim of the CORINE land cover project was setting up a spatial database of land use and vegetation cover in the GIS environment, which could serve as a basis for decision making and design of environmental policy on regional and European levels. In Slovenia, the CORINE project was managed within the PHARE programme from September 1996 to November 1998. During the data capture a classification table was used with 44 classes in three levels offering the comparability with the databases in various European countries.

\section{Catalogue of large scale topographic maps (TNN VM 500)}

The objective of production of topographic maps in larger scale is to capture detailed spatial data 
in cities, towns and settlements and other spatial areas where there are intensive spatial activities taking place. For these areas the Basic Geodetic Survey Act (1974) defines the topographic maps in the scales of 1:500, 1:1000, 1:2000, and 1:2500.

\section{Catalogue of the topographic database (TOPO 5)}

The topographic database of higher precision (TOPO5) has been produced as an attempt to rationalise the maintenance of analogue topographic data (scales of 1:5000 and 1:10,000) and to adapt to modern user requirements.

It serves also as a background for map production of smaller scale with generalisation. The database is produced by 8 different data sources and various methods. The data are classified in three levels of geometric and semantic relationships. The data model comprises 20 concepts.

\section{Catalogue of spatial shapes}

The aim of establishing the Catalogue of spatial shapes (at the The Surveying and Mapping Authority of the Republic of Slovenia) is decision support to ONIX geoinformation projects in domains of spatial planning, real estate management and environmental protection. Spatial shapes are grouped hierarchically in collections and groups of concepts, which represent objects with one or more common attributes. The catalogue contains an index and descriptions of concepts. The index represents the whole content of the catalogue, while the descriptions set the attributes for every concept. The description includes the name of the concept, a possible synonym, a description of spatial phenomena, the geometric (topologic) definition, and a code number.

\subsection{Analysis of semantic correspondence of UOGS}

We have performed an analysis of semantic suitability between the above described catalogues of spatial data with the UOGS semantic reference network. The description of relations between symbol catalogues, application ontologies and concept ontologies form the domain ontology of UOGS. The definition of relations between the symbols of catalogues, the ontologies of applications and the concepts of domain ontology is performed in the relevant tables (Čeh, 2003). Their relations are estimated by two basic semantic relationships:

- Relationship of equivalent classes of domain ontology and classes of application ontology;

- Relationship of an aggregate of two or more concepts of domain ontology and classes of application ontology;

- Non-adequate relationship for the classes of application ontology not existing in domain ontology.

The above relationships were expressed by the formulas:

Equivalent $=$ referring_to_equivalent_class

Aggregate $=$ referring_to_aggregate_class

Non-adequate $=$ referring_to_non-adequate _class

Each applicative catalogue is firstly translated into UOGS and enriched by the concepts of it. 
The catalogue is also attributed with metadata concerning the semantic relation of its classes towards UOGS concepts (Equivalent, Aggregate, Non-adequate).

\begin{tabular}{|l|c|c|c|c|c|c|c|}
\hline & \multicolumn{5}{|c|}{$\begin{array}{c}\text { Metadata } \\
\text { of semantic relationships }\end{array}$} & \multicolumn{2}{c|}{$\begin{array}{c}\text { Semantic } \\
\text { correspondence } \\
\text { UOGS (\%) }\end{array}$} \\
\hline Catalogue & $\begin{array}{c}\text { Equival. } \\
\text { (e) }\end{array}$ & $\begin{array}{c}\text { Aggreg. } \\
\text { (a) }\end{array}$ & $\begin{array}{c}\text { Non-adeq. } \\
\text { (n) }\end{array}$ & $\begin{array}{c}\text { Sum } \\
(\mathrm{e}+\mathrm{a}+\mathrm{n})=\mathrm{s}\end{array}$ & $(\mathrm{e}+\mathrm{a})$ & $(\mathrm{e}+\mathrm{a}) / \mathrm{s}$ & (n) \\
\hline Land use - Cadastre & 31 & 5 & 6 & 42 & 36 & 86 & 14 \\
\hline Land use - LPIS & 34 & 15 & 9 & 58 & 49 & 84 & 16 \\
\hline $\begin{array}{l}\text { Topographic maps in larger } \\
\text { scale (TTN VM 500) }\end{array}$ & 155 & 56 & 3 & 214 & 211 & 99 & 1 \\
\hline $\begin{array}{l}\text { Topographic database of higher } \\
\text { precision (TOPO 5) }\end{array}$ & 10 & 1 & 5 & 16 & 11 & 69 & 31 \\
\hline CORINE Land Cover & 27 & 27 & 5 & 59 & 54 & 92 & 8 \\
\hline $\begin{array}{l}\text { Catalogue of spatial shapes } \\
\text { (SMARS) }\end{array}$ & 95 & 60 & 7 & 162 & 155 & 96 & 4 \\
\hline Total & 352 & 164 & 35 & 551 & 516 & 94 & 6 \\
\hline & $64 \%$ & $30 \%$ & $6 \%$ & $100 \%$ & & & \\
\hline
\end{tabular}

Table 1: Examples of calculation of UOGS semantic correspondence.

Semantic relations between the UOGS concepts and the concepts of catalogues were considered for six databases of spatial data in the Republic of Slovenia. Semantically related concepts of each database were summed up in column $(e+a)$ in Table 1 . We compared them with the total number of concepts for each catalogue and expressed the ratio in percentage in column $(e+a) / s$.

Approximately $94 \%$ of totally 551 concepts from the processed catalogues were expressed with the catalogue of knowledge in UOGS. The result confirms a high level of semantic correspondence of the created ontology even more, since it was not a result of joining existing databases, but as an independent taxonomy. The high level of semantic correspondence also indicates the universality for use in the domain of geographic space. For that reason the UOGS is an appropriate tool for discovery of semantic correspondence of different spatial databases. The number of semantically non-adequate concepts is represented in column ( $n$ ) and is further represented in the next chapter.

\subsection{Analysis of semantically non-adequate concepts}

Since certain concepts of processed catalogues cannot be expressed with the concepts of UOGS we performed additional analyses of semantically non-adequate concepts from the processed catalogues (Table 2).

The results of analyses uncover that as a non-adequate concept spatial expression »land « (12 times) appears most often. It is followed by spatial expressions »structure « ( 7 times), »area ( 4 times), »building « (3 times) and »object « (3 times). Most dominant are therefore the expressions »land « and »structure«. The expressions »other« and »secondary « will not be considered further since they are not related to the concept of space. 


\begin{tabular}{|l|c|c|c|c|c|c|}
\hline & \multicolumn{5}{|c|}{ Term in semantically non-adequate concepts } \\
\hline Catalogue & building & structure & object & land & area & other, secondary \\
\hline Land use - Cadastre & 2 & 1 & 1 & 2 & 1 & \\
\hline Land use - LPIS & & & & 7 & & 5 \\
\hline Topographic maps in larger scale (TTN VM 500) & 1 & 1 & & & & 1 \\
\hline Topographic database of higher precision (TOPO 5) & & 1 & 1 & 1 & & \\
\hline CORINE Land Cover & & & & & 3 & \\
\hline Catalogue of spatial shapes (NLS) & 4 & & 1 & 2 & & \\
\hline Total & 7 & 3 & 3 & 12 & 4 & 7 \\
\hline
\end{tabular}

Table 2: Analysis of semantically non-adequate concepts.

In this chapter the results of analyses were presented which will be discussed in the next chapter.

\section{DISCUSSION}

The practical application of the research is based on the results of the analysis. The term »land « is semantically proven as a synonym for the term »space«, which in UOGS represents the origin. As an origin of ontology the term »space« is exceedingly general and for that reason practically inappropriate for the labelling of concepts. Obviously the term »land « was used prevailingly for denoting »space« also in the catalogue of Slovenian agricultural Land Parcel Identification System (LPIS). In this catalogue the term »land « appears 7 times. Similarly, it could be claimed that the term »area « is used to express a general concept of space, however through its homonym meaning "plane«. For that reason it is possible to derive an equivalent relation between the concepts »space-plane-land « and jointly spatial »plane-land», respectively.

We continue the discussion of semantically non-adequate concepts with the second most frequently appearing term "structure« (7 times), which is joined semantically by synonyms »building « (3 times) and the term »object« (3 times). For this group of terms it is also possible to derive an equivalent relation between the concepts »structure-building-object «. Compared to the numeric results the term »structure« in this relation has a slightly dominant role.

If we sum up the terms for these concepts from the viewpoint of cognitive sensing, it is possible to claim that the concept of space on its most general level comprises two elements:

- "plane-land«; the element that humans perceive as open space, and

- "structure-building-object«; the element which is perceived by humans as three-dimensional blocks of more or less regular shape and, for that reason, we infer its artificial origin.

Both elements are the representation of the concept of space, which could be represented as a union:

Space $=[$ plane - land $] \cup[$ structure - building - object $]$

which represents the origin of UOGS.

In defining the concepts of space for practical use (e.g. in a spatial database) it is necessary to 
surpass the generality of the indicated terms. If it is not possible to avoid their use, it is necessary to enrich their semantics with adding the terms, which are less general from the semantic viewpoint or they have a larger semantic depth. Such terms are connected with the concepts of human activities in the geographic space as explained in full in Čeh (2003).

\section{CONCLUSION}

The management of a spatial database in independent distributed information systems is a reality. Effective automatic integration of such a database is expected in near future. The structural interoperability of systems for management of spatial data is subject to technological development, which offers the solutions as standards for GIS. Semantic interoperability of the knowledge about the space is the topic of contemporary research.

Semantic intelligent search and integration of information includes the composition of a system of knowledge for data integration. It is about keeping the meaning of information entities in different contexts, which can be considered as a classification task.

Ontology is treated as the most important means for solving the problems of semantic heterogeneity of information systems. In the ontological approach the explicit definition of terms used in information systems is applied. Ontologies are used for better communication between humans and computers. The interoperability between various computer systems is achieved with translation and adjustment of the meaning of different methods of modelling, language and programming tools. There the ontology is used as the metadata reference system.

For successfully connecting information it is necessary to develop the methods that offer a solution for terminological and conceptual incompatibility. The first attempts of developing the appropriate methods were based on single case databases and documents. It became obvious that it was necessary to develop a standard ontology of the highest level as it was used in our research.

We have used the definition of Universal Ontology of Geographic Space (UOGS, Čeh, 2003). On its basis we executed semantic querying and integration of data in the spatial database. The meaning of terms used for denoting spatial objects in reality is explained with the arrangement of those terms into the UOGS conceptual framework. It also consists of semantic vocabulary. In design of the conceptual framework we took into consideration the outcomes of ontological research and of the first-order predicate calculus (logic).

Applicative results of the conducted research have shown that $94 \%$ of the concepts that are comprised in analysed spatial databases are describable with the concepts of UOGS. Each concept of a given database has been described as equivalent or aggregate of concepts from UOGS. The rest (6\%) of concepts are too general from the UOGS point of view (for instance »land «, "parcel«, »object«), therefore they are not semantically explainable in UOGS without semantic enrichment. We have ascertained that the developed UOGS model is reliable, and it provides a comprehensive tool for application of semantic enrichment of spatial concepts. 


\section{References:}

Berners-Lee, T. (2010). Long Live the Web, Scientific American, 303 (6), 80-85.

Berners-Lee, T., Hendler, J., Lassila, O. (2001). The Semantic Web, Scientific American, 29-37.

Bratko, I. (2001). Prolog programming for artificial intelligence. 3rd ed. Harlow (England): Addison-Wesley.

Brickley, D., Guha, R. (2004). RDF Vocabulary Description Language 1.0: RDF Schema. W3C Recommendation; accessed 1 July 2011: http://www.w3.org/TR/2004/REC-rdf-schema-0040210

Čeh, M. (2003). Semantična integracija zbirk prostorskih podatkov. Založba ZRC, ZRC SAZU Ljubljana.

Čeh, M., Podobnikar, T., Smole, D. (2004). Geodata - are they accessible and useful?. In: Toppen, F. (ed.). AGILE 7th conference on Geographic Information Science, Heraklion, Greece. Conference proceedings. Heraklion, 2004: Crete University, 789-794.

Čeh, M., Podobnikar, T., Smole, D. (2006). Semantic similarity measures within the semantic framework of the universal ontology of geographical space. In: Riedl, A. (ed.). Progress in spatial data handling : 12th International Symposium on Spatial Data Handling. Berlin [etc.]: Springer, 417-434.

Devogele, T., Parent, T., Spaccapietra, S. (1998). On spatial database integration. International Journal Geographic Information Science, 12, (4), Taylor and Francis, London, Great Britain.

Džeroski, S., Lavrač, N. (2001). An introduction to inductive logic programming. In: Džeroski, S., Lavrač, N. eds.) Relational data mining. Berlin: Springer-Verlag, 48-73.

Egenhofer, M, Mark, D. (1995). Na ve geography. COSIT'95, LNCS 988, Springer Verlag, Berlin, Germany.

Ester, M., Kriegel, H., Sander, J. (1997). Spatial Data Mining: A Database Approach. Advances in Spatial Databases, 5th International Symposium, SSD '97, Berlin, Germany.

Hayne, S., Ram., S. (1990). Multi-user View Integration System (MUVIS): An Expert System for View Integration. 6th IEEE Conference on data engineering, Los Angeles, USA.

Keim, D., Kriegel, H., Seidel., T. (1994). Supporting Data Mining of Large Databases by Visual Feedback Queries. Proceedings of IEEE 10th International Conference on Data Engineering, Houston, IEEE Comput. Soc. Press, Los Alamitos, California, USA.

Knorr, E., Ng, R., Shilvok, D. (1997). Finding Boundary Shape matching Relationships in Spatial Data, Advances in Spatial Databases. 5th International Sympsium, SSD '97, Berlin, Germany.

Kononenko, I. (2005). Strojno učenje - 2. popravljena in dopolnjena izdaja, Fakulteta za računalništvo in informatiko, Ljubljana.

Leung, Y. (1997). Intelligent spatial decision support systems. Springer Verlag, Berlin, Germany.

Miller, H. J. (2008). Geographic Data Mining and Knowledge Discovery, The Handbook of Geographic Information Science, J. P. Wilson and A. S. Fotheringham (eds.), Blackwell Publishing Ltd, Oxford, UK.

Pivk, A. (2005). Avtomatska gradnja ontologij iz spletnih tabel. Doktorska disertacija, Univerza v Mariboru.

Podobnikar, T. Čeh. M. (2012 ). Preface In: Podobnikar, T., Čeh. M. (eds.). Universal Ontology of Geographic Space: Semantic Enrichment for Spatial Data. IGI Global, 2012. 0-304. Web. 12 Mar. 2012. doi:10.4018/978-1-4666-0327-1

Sester, K., Anders, K., Walter, V. (1998). Linking objects of different spatial data sets by integration and aggregation. Geoinformatica, 2 (4). Kluwer Academic Publishers, Dordrecht, The Netherlands.

Smole, D., Čeh, M., Podobnikar, T. (2011). Evaluation of Inductive Logic Programming for Information Extraction from Natural Language Texts to Support Spatial Data Recommendation Services. International Journal of Geographical Information Science.

Spaccapietra, S., Parent, C., Dupont, Y. (1992). Model independent assertions for integration of heterogenious schemas. VLDB Journal, Vol. I, Springer Verlag, Germany.

Vet, P., Mars, N. (1998). Bottom-up construction of ontologies. IEEE Transactions on knowledge and data engineering, 10 (4), IEEE Computer Society.

Zakon o zemljiškem katastru, Uradni list SRS, št. 16/74, UL SRS, št. 42/86.

Pravilnik o vodenju vrst rabe zemljišč v zemljiškem katastru, Uradni list UL SRS, št. 41/82.

Zakon o temeljni geodetski izmeri, Uradni list SRS, št. 16-142/74. 
Received for publication: 4. October 2011

Accepted: 16. February 2012

Dr. Marjan Čeh, Univ. Grad. of Geod. Eng.

UL FGG - Department of Geodesy, Jamova cesta 2, SI-1000 Ljubljana, Slovenia

e-mail: marjan.ceh@fgg.uni-lj.si, tel.: (01) 4768653

\section{MSc Domen Smole, Univ. Grad. of Geod. Eng.}

DFG Consulting, Pivovarniška ulica 8, SI-1000 Ljubljana, Slovenia

e-mail:domen.smole@dfgcon.si

Assist. Prof. Dr. Tomaž Podobnikar, Univ. Grad. of Geod. Eng., research advisor

ZRC SAZU - Institute of anthropological and spatial studies, Novi trg 2, SI-1000 Ljubljana, and UL FGG - Department of Geodesy, Jamova cesta 2, SI-1000 Ljubljana, Slovenia e-mail: tomaz.podobnikar@fgg.uni-lj.si 